\title{
FVC, FEV1 and FEV1/FVC \% in Female SLE Patients and Their Relationship with Duration of the Disease
}

\author{
Hussain $\mathrm{D}^{1}$, Begum $\mathrm{S}^{2}$, Ali $\mathrm{T}^{3}$, Ahmed $\mathrm{MNU}^{4}$, Farzana $\mathrm{R}^{5}$
}

\begin{abstract}
Systemic Lupus Erythematosus (SLE) is an autoimmune disorder which affects multiple organs of human including lungs.

To assess FVC, FEV and FEV /FVC \% in SLE patients and to correlate them with the duration of the disease.

This cross-sectional study was carried out in the Department of Physiology, BSMMU, Dhaka, from January 2010 to December 2010. A total number of 120 female subjects were selected, among which 30 were age and BMI matched apparently healthy subjects for comparison (control) and 90 were patients of SLE (study group). Ages of all the patients were ranged from 20 to 50 years and they were matched in terms of age, sex and BMI. Based on the duration of the disease, patients were subdivided into $B_{1}$ (1-6 months), $B_{2}$ (2-5 years) and $B_{3}$ (6-10 years). Controls were selected from the community and the patients from the Out Patient Department (OPD) of SLE clinic, Department of Medicine, BSMMU, Dhaka. Lung function were assessed by measuring Forced vital capacity (FVC), Forced expiratory volume in $1^{\text {st }}$ second $\left(F E V_{1}\right)$, Forced expiratory ratio ( $\left.F E V_{l} / F V C \%\right)$ with a Digital MicroDL spirometer. For statistical analysis Independent Sample ' $t$ ' test, One way ANOVA test and Pearson's correlation coefficient test were performed as applicable.
\end{abstract}

The mean percentage of predicted values of lung function parameters in healthy female subjects were within normal ranges. The mean percentage of predicted values of $F V C$, $F E V_{1}$ were significantly lower in all study groups when compared to control. Again, the mean percentage of predicted values of FVC, FEV significantly lower in the patients of Group $B_{3}$ compared to Group $B_{2}$ except FVC which were non significantly lower. Moreover, these comparisons were significantly lower when compared to Group $B$. The differences of the mean percentage of predicted values of $F V C$,

1. Corresponding Author : Dilroze Hussain

Assistant professor, Department of Physiology

Kumudini Women`s Medical College, Mirjapur,Tangial

Email: dilrozehussain@gmail.com

2. Shelina Begum

Professor, Department of Physiology

Bangabandhu Sheikh Mujib Medical University, Dhaka

3. Taskina Ali

Associate Professor, Department of Physiology

Bangabandhu Sheikh Mujib Medical University, Dhaka

4. Mohammed Nesar Uddin Ahmed

Associate Professor(CC),Department of Physiology

Ad-din Akij Medical College, Boyra, Khulna.

5. Refat Farzana

Assistant professor, Department of Microbiology

Kumudini women`s Medical College, Mirjapur, Tangial.
$F E V_{1}$ were significantly lower in Group $B_{2}$ when compare to Group $B_{1}$. In addition, FVC and $F E V_{1}^{2}$ were positively correlated in $B_{2}$ and $B_{3}$ when correlated with duration of SLE. All these values were statistically non significant. In addition The mean percentage of predicted values of FEV/ $F V C \%$ were almost similar and the differences among the groups were statistically non-significant.

Pulmonary function decrease in SLE female and the reduction is inconsistently associated with duration of the disease.

Key words: SLE, FVC, FEV $F E V_{1} / F V C \%$

\section{Introduction}

Systemic Lupus Erythematosus (SLE) is the most common multisystemic disorder mediated through the immune system of the human body. Clinical features of SLE include malar rash, discoid rash, photosensitivity, oral ulcers, arthritis, serositis, renal disorder, neurological disorder as well as hematological disorder ${ }^{1}$.SLE is about nine times as common in women as in $\mathrm{men}^{2}$. They also suggested that, the peak age of onset of this multisystemic disorder might be 20 to 40 years. The prevalence of SLE in the USA is approximately 15 to 50/100000 of which highest is among African Americans ${ }^{1}$. In other population the prevalence varies between 1:1000 and $1: 10000^{3}$.In India found a point prevalence of 3 per $100000^{4}$. There is no standard statistical data in SLE in Bangladesh ${ }^{3}$.

Several investigators of different countries abroad reported lower spirometric lung variables in SLE patients ${ }^{6,8,9,10}$, which might be decreased with duration of disease ${ }^{11,12,13}$.

The disease course of SLE may be followed by spontaneous remission and relapses and severity may vary from a mild episodic disorder to life-threatening illness ${ }^{4}$. For that, the SLE affected subjects in Bangladesh are usually treated by the physician with an aim to relieve the symptoms ignoring the prevention and curative treatment of any organic complication along with pulmonary complications. As a consequence, pulmonary involvement in SLE may remain undiagnosed for a long period in this group of morbid patients. Early diagnosis of lung involvement is beneficial in most patients for therapy and could have an important effect on therapeutic strategies ${ }^{7,14}$.Therefore early detection of lung involvement is important in patients with $\mathrm{SLE}^{6}$.

Many researchers have investigated pulmonary functions in this group of patient abroad $d^{5,8,9,10,11,12,15}$. In our country, several researchers studied on $\mathrm{SLE}^{3,16}$ on different aspects of SLE, such as SLE in pregnancy and coetaneous involvement. With the best of our knowledge, no such study has been undertaken to explore the pulmonary function status in this group of patients in Bangladesh. Therefore the present study was designed to observe $\mathrm{FVC}, \mathrm{FEV}_{1}$ and $\mathrm{FEV} 1 / \mathrm{FVC} \%$ in this group of female patients and also to evaluate their association with duration of this disease. The outcome of this study may act as a source of background information for guiding the clinicians about the risk of pulmonary complications while treating the SLE patients. 


\section{Meterials \& Methods}

For this study, 90 female patients of SLE were selected from the Out Patient Department (OPD) of SLE clinic, Department of Medicine, BSMMU, Dhaka (study group).The study group was selected according to the updated American College of Rheumatology (ACR) revised criteria of $\mathrm{SLE}^{24}$. In this study, the study population was subdivided into $\mathrm{B}_{1}$ (1-6 months), $\mathrm{B}_{2}$ (2-5 years) and $\mathrm{B}_{3}$ (6-10 years) on the basis of duration of disease. Disease duration was characterized as the duration from the date of physician diagnosis until the date at first study visit. For comparison, 30 ages (20 to 40 years), BMI (19.73 to $25.6 \mathrm{~kg} / \mathrm{m}^{2}$ ) matched apparently healthy female persons (control) were collected from different areas of Dhaka city by personal contact.

After selection, all the subjects were thoroughly informed about the aim, benefit and study procedure. Informed written consent was obtained.She was requested to attend the Department of Physiology at 7.30 am in a fasting state on the day of examination. Then she was requested to attend the Department of Physiology at 7.30 am in a fasting state on the day of examination.A detail personal, medical, family, socioeconomic, occupational and dietary history was recorded in a preformed questionnaire. Thorough physical examination was done and documented. Any subject with diabetes mellitus (Fasting plasma glucose $>7 \mathrm{mmol} / \mathrm{dl}^{26}$ ) or with $\mathrm{H} / \mathrm{O}$ diagnosis of systemic hypertension ( $\mathrm{SBP} \geq 140$ and $\mathrm{DBP} \geq 90 \mathrm{~mm}$ of $\mathrm{Hg}^{25}$ ), with $\mathrm{H} / \mathrm{O}$ any pulmonary comorbidity (e.g, bronchiectasis, pulmonary fibrosis, pneumonectomy, lobectomy) or any other systemic disease (e.g, rheumatoid arthiritis, connective tissue disorder) or with $\mathrm{H} / \mathrm{O}$ any heart disease, renal insufficiency $(>1.5 \mathrm{mg} / \mathrm{dl})$ were excluded from the study ${ }^{27}$. All the subjects were under drug treatment and do not have the clinical symptoms and sign of lung disease.

Then the subject was examined for the lung function parameters by using a Digital Spirometer, described by Clement Clark International, in the Respiratory laboratory of Department of Physiology, BSMMU (Annexure-1). Lung function was assessed by measuring Forced vital capacity (FVC), Forced expiratory volume in $1^{\text {st }}$ second $\left(\mathrm{FEV}_{1}\right)$, Forced expiratory ratio $\left(\mathrm{FEV}_{1} / \mathrm{FVC} \%\right)$. Body Weight was recorded during spirometry.

Data were expressed as mean $\pm \mathrm{SD}$ (Standard deviation). Oneway ANOVA test was done to compare among the groups and Independent sample ' $t$ ' test was done to compare between the groups. Pearson's Correlation Coefficient test was done to correlate the spirometric variables with duration of disease. $p$ value $<0.05$ was accepted as level of significance.

\section{Results}

The mean \pm SD of age and BMI of all the subjects were almost similar and groups were matched for age and BMI (Table I).

The mean percentage of predicted values of lung function parameters in healthy female subjects were within normal ranges.

Table I:Age and BMI in different groups $(n=120)$

\begin{tabular}{ccc}
\hline Groups & Age (Years) & BMI $\left(\mathbf{K g} / \mathbf{m}^{2}\right)$ \\
\hline $\mathrm{A}(\mathrm{n}=30)$ & $30.9 \pm 5.5$ & $22.56 \pm 1.33$ \\
& $(20-39)$ & $(19.73-25.14)$ \\
$\mathrm{B}_{1}(\mathrm{n}=30)$ & $28.8 \pm 4.08$ & $22.66 \pm 1.8$ \\
& $(21-36)$ & $(18.66-26.16)$ \\
$\mathrm{B}_{2}(\mathrm{n}=30)$ & $29.2 \pm 4.5$ & $22.84 \pm 1.5$ \\
& $(21-40)$ & $(18.97-26.75)$ \\
$\mathrm{B}_{3}(\mathrm{n}=30)$ & $29.5 \pm 5.2$ & $23.02 \pm .9$ \\
& $(20-42)$ & $(21.33-25.2)$ \\
\hline
\end{tabular}

\section{Statistical analysis:}

\begin{tabular}{ccc}
\hline Groups & p value (Age) & p value (BMI) \\
\hline $\mathrm{A} v s ~ B_{1}$ vs B $_{2}$ vs B $_{3}^{\mathrm{a}}$ & $0.414^{\mathrm{ns}}$ & $0.443^{\mathrm{ns}}$ \\
$\mathrm{A} v \mathrm{vs} \mathrm{B}_{1}^{\mathrm{b}}$ & $0.102^{\mathrm{ns}}$ & $0.810^{\mathrm{ns}}$ \\
$\mathrm{Avs} \mathrm{B}_{2}^{\mathrm{b}}$ & $0.219^{\mathrm{ns}}$ & $0.450^{\mathrm{ns}}$ \\
$\mathrm{Avs} \mathrm{B}_{3}{ }^{\mathrm{b}}$ & $0.333^{\mathrm{ns}}$ & $0.126^{\mathrm{ns}}$ \\
$\mathrm{B} 1$ vs B $_{2}{ }^{\mathrm{b}}$ & $0.677^{\mathrm{ns}}$ & $0.682^{\mathrm{ns}}$ \\
$\mathrm{B} 1$ vs B $_{3}{ }^{\mathrm{b}}$ & $0.549^{\mathrm{ns}}$ & $0.351^{\mathrm{ns}}$ \\
$\mathrm{B} 2$ vs B $_{3}{ }^{\mathrm{b}}$ & $0.834^{\mathrm{ns}}$ & $0.598^{\mathrm{ns}}$ \\
\hline
\end{tabular}

Data were expressed as mean $\pm \mathrm{SD}$. Figures in parentheses indicate ranges.

$\mathrm{a}=$ one way ANOVA, $\mathrm{b}=$ independent sample $\mathrm{t}-$ test.

$\mathrm{BMI}=$ Body Mass Index

Group A: Apparently healthy subjects (control group)

Group B: SLE patients (study group)

$\mathrm{B}_{1} \quad$ : Patients with 1-6 months.

$\mathrm{B}_{2} \quad$ : Patients with $2-5$ yrs.

$\mathrm{B}_{3} \quad$ : Patients with 6-10 yrs.

$* * *=$ significant $(\mathrm{p}<0.001)$

** = significant $(\mathrm{P}<0.01)$

* $\quad=$ significant $(\mathrm{P}<0.05)$

ns $\quad=$ non significant $(\mathrm{p}>0.05)$

$\mathrm{n} \quad=$ number of subjects

The mean percentage of predicted values of lung function parameters in healthy female subjects were within normal ranges.

The results of all the lung function parameters are shown in Table II 
Table II: Mean percentage of predicted value of $\mathrm{FVC}$, $\mathrm{FEV}_{1}$ and $\mathrm{FEV}_{1} / \mathrm{FVC} \%$ in different groups $(\mathbf{n}=\mathbf{1 2 0})$

\begin{tabular}{|c|c|c|c|}
\hline Groups & $\mathrm{FVC}$ & $\mathrm{FEV}_{1}$ & $\mathrm{FEV}_{1} / \mathrm{FVC}^{\circ}$ \\
\hline $\mathrm{A}(\mathrm{N}=30)$ & $\begin{array}{c}94.26 \pm 7.22 \\
(80-106)\end{array}$ & $\begin{array}{c}88.43 \pm 6.90 \\
(80-105)\end{array}$ & $\begin{array}{l}95.3 \pm 7.32 \\
(85-107)\end{array}$ \\
\hline $\mathrm{B}_{1}(\mathrm{~N}=30)$ & $\begin{array}{c}84.06 \pm 17.42 \\
(55-133)\end{array}$ & $\begin{array}{c}81.93 \pm 12.32 \\
(57-104)\end{array}$ & $\begin{array}{l}94.43 \pm 14.14 \\
(64-113)\end{array}$ \\
\hline $\mathrm{B}_{2}(\mathrm{~N}=30)$ & $\begin{array}{c}75.7 \pm 13.87 \\
(42-101)\end{array}$ & $\begin{array}{c}71.03 \pm 14.90 \\
(47-100)\end{array}$ & $\begin{array}{l}93.56 \pm 16.27 \\
(43-112)\end{array}$ \\
\hline $\mathrm{B}_{3}(\mathrm{~N}=30)$ & $\begin{array}{c}70.1 \pm 11.86 \\
(51-94)\end{array}$ & $\begin{array}{c}63.8 \pm 10.10 \\
(43-81)\end{array}$ & $\begin{array}{l}92.7 \pm 14.18 \\
(47-112)\end{array}$ \\
\hline
\end{tabular}

Statistical analysis:

\begin{tabular}{|c|c|c|c|}
\hline Groups & p value & p value & p value \\
\hline$A$ vs $B_{1} v B_{2} v_{s ~ B}{ }^{a}$ & $0.000 * * *$ & $0.000 * * *$ & $0.919^{\mathrm{ns}}$ \\
\hline $\mathrm{A}$ vs $\mathrm{B}_{1}^{\mathrm{b}}$ & $0.004 * *$ & $0.015 * *$ & $0.767^{\text {ns }}$ \\
\hline $\mathrm{A}$ vs $\mathrm{B}_{2}^{\mathrm{b}}$ & $0.000 * * *$ & $0.000 * * *$ & $0.597^{\mathrm{ns}}$ \\
\hline $\mathrm{A}_{\mathrm{vs}} \mathrm{B}_{3}$ & $0.000 * * *$ & $0.000 * * *$ & $0.377^{\text {ns }}$ \\
\hline $\mathrm{B}_{1} \mathrm{vs} \mathrm{B}_{2}^{\mathrm{b}}$ & $0.04^{*}$ & $0.003 * *$ & $0.826^{\mathrm{ns}}$ \\
\hline $\mathrm{B}_{2} \mathrm{vs} \mathrm{B}_{3}^{\mathrm{b}}$ & $0.098^{\mathrm{ns}}$ & $0.032 *$ & $0.637^{\mathrm{ns}}$ \\
\hline $\mathrm{B}_{1} \mathrm{vs} \mathrm{B}_{3}^{\mathrm{b}}$ & $0.001 * * *$ & $0.000 * * *$ & $0.826^{\mathrm{ns}}$ \\
\hline
\end{tabular}

Data were expressed as mean \pm SD. Figures in parentheses indicate ranges.

$\mathrm{a}=$ one way ANOVA, $\mathrm{b}=$ independent sample $\mathrm{t}$ - test.

Group A: Apparently healthy subjects (control group)

Group B: SLE patients (study group)

$\mathrm{B}_{1} \quad$ : patients with 1-6 months.

$\mathrm{B}_{2} \quad$ : Patients with 2-5 yrs.

$\mathrm{B}_{3} \quad$ : Patients with 6-10 yrs.

$* * * \quad=$ significant $(\mathrm{p}<0.001)$

$* * \quad=$ significant $(\mathrm{P}<0.01)$

$* \quad=$ significant $(\mathrm{P}<0.05)$

ns $\quad=$ non significant $(\mathrm{p}>0.05)$

$\mathrm{n} \quad=$ number of subjects

The mean percentage of predicted values of FVC, FEV were significantly lower in all study groups when compared to control. Again, the mean percentage of predicted values of $\mathrm{FVC}, \mathrm{FEV}_{1}$ significantly lower in the patients of Group $\mathrm{B}_{3}$ compared to Group $\mathrm{B}_{2}$ except FVC which were non significantly lower. Moreover, these comparisons were significantly lower when compared to Group $B_{1}$. The differences of the mean percentage of predicted values of $\mathrm{FVC}, \mathrm{FEV}_{1}$ were significantly lower in Group $\mathrm{B}_{2}$ when compare to Group $\mathrm{B}_{1}$ In addition The mean percentage of predicted values of $\mathrm{FEV}_{1} / \mathrm{FVC} \%$ were almost similar and the differences among the groups were statistically nonsignificant. FVC and $\mathrm{FEV}_{1}$ were positively correlated in $\mathrm{B}_{2}$ and $\mathrm{B}_{3}$ when correlated with duration of SLE. All these values were statistically non significant.
Figure I: Correlation of percentage predicted value of $\mathrm{FVC}$ with duration of SLE in different groups $(n=60)$

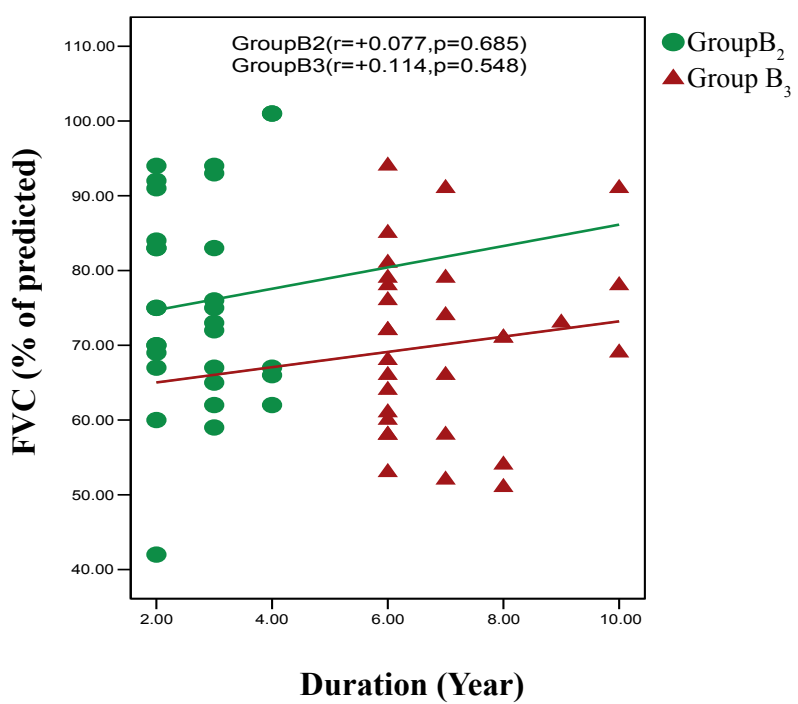

Statistical analysis was done by Pearson's correlationcoefficient (r)

Group B: SLE patients (study group)

$$
\begin{aligned}
& \mathrm{B}_{2}: \text { 2-5 years duration } \\
& \mathrm{B}_{3:}: 6-10 \text { years duration }
\end{aligned}
$$

Figure II: Correlation of percentage predicted value of $\mathbf{F E V}$, with duration of SLE in different groups $(n=60)$

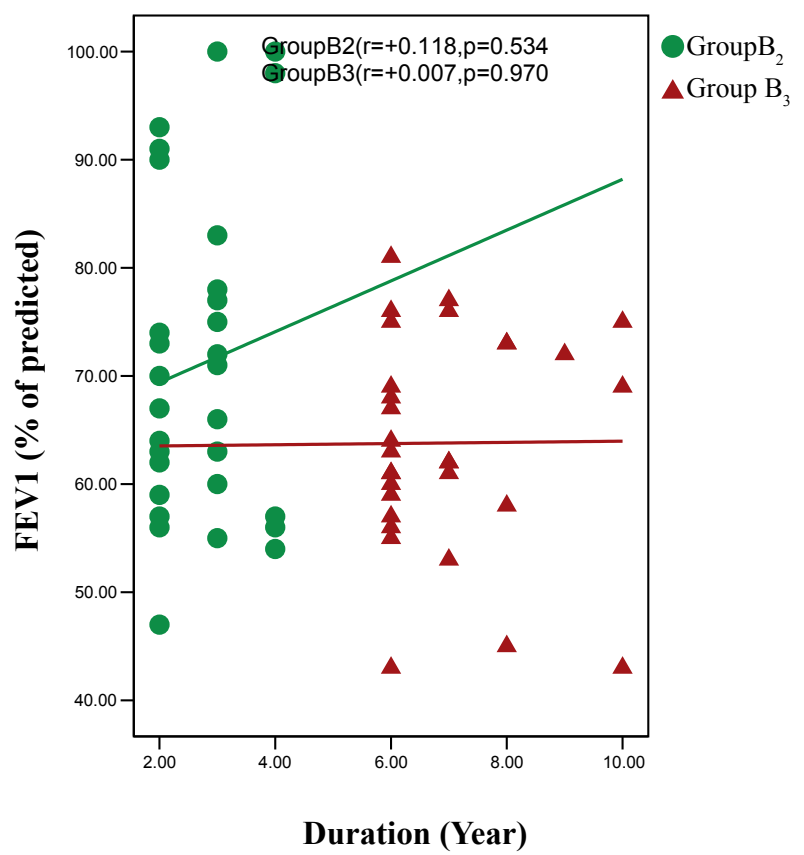

Statistical analysis was done by Pearson's correlationcoefficient (r) test.

Group B: SLE patients (study group)

$$
\begin{aligned}
& \mathrm{B}_{2}: 2-5 \text { years duration } \\
& \mathrm{B}_{3:} \text { 6-10 years duration }
\end{aligned}
$$




\section{Discussion}

The present study was undertaken to observe some aspects of spirometric pulmonary function in female patients of SLE in order to evaluate their pulmonary function status and correlate them with the duration of the disease. Therefore, FVC, $\mathrm{FEV}_{1}, \mathrm{FEV}_{1} / \mathrm{FVC} \%$ were analyzed in patients with different duration of SLE. All these parameters were also studied in apparently healthy age and BMI matched female subjects for comparison.

In this study, values of lung function parameters of healthy subjects were within physiological limit and were almost similar to those reported by different investigators of abroad ${ }^{10}$ as well as in our country ${ }^{17,18}$.

In the current study, FVC in patients of SLE of different duration were significantly $(p<0.001)$ lower than those of apparently healthy subjects. Almost similar findings were observed by several investigators from different countries $^{11,12,19,20}$. Again, this variable was significantly lower in group $B_{2}$ when compared to $B_{1}(p<0.05)$. These finding were in agreement with that of ${ }^{12}$. However, this parameter was significantly $(p<0.001)$ lower in group $B_{3}$ comparison to patients of $\mathrm{B}_{1}$. But this difference was not significant in patients with $\mathrm{B}_{2}$. No similar observation was available for comparison.

$\mathrm{FEV}_{1}$ in patients of SLE were significantly $(\mathrm{p}<0.001)$ lower than those of control and these findings were supported by different investigators from different countries ${ }^{10,19,29}$. Moreover, this parameter was significantly lower in group $B_{2}$ compared to $B_{1}(p<0.01)$. However, this parameter was significantly lower in group $\mathrm{B}_{3}$ compared to $\mathrm{B}_{1}(\mathrm{p}<0.05)$ and $\mathrm{B}_{2}(\mathrm{p}<0.001)$ of disease. No similar observation was available for comparison. $\mathrm{FEV}_{1} / \mathrm{FVC}$ ratio were similar in all groups.

$\mathrm{FVC}$ and $\mathrm{FEV}_{1}$ were positively correlated in $\mathrm{B}_{2}$ and $\mathrm{B}_{3}$. Again, FEV1/FVC ratio was positively correlated with the duration of disease in group $\mathrm{B}_{2}$ but negatively correlated in $\mathrm{B}_{3}$.

The exact mechanism of development of pulmonary lesion in SLE is not clear. Several investigators of different countries suggested different mechanism for lung involvement. Antibody mediated direct cell injury may cause the alveolar damage $^{22,30}$. They also suggested that immune complex mediated injury, vasculitis of alveolar capillaries and alveolar damage related to infection probably play a role.

Decreased lung compliance in SLE indicates restrictive features which were probably due to interstitial fibrosis due to inflammatory changes of interstitial tissue ${ }^{1,20,21}$.Moreover, some researchers suggested restriction of lung volumes can be due to pleurisies and pleural effusions ${ }^{9,21,22,23}$. Few other researchers suggested that type II pneumocyte hyperplasia, alveolar septal immune deposits, lymphatic infiltration and alveolar septal thickening might cause chronic interstitial lung disease $\mathrm{e}^{8,31}$. In addition, some researchers suggested that weakness of inspiratory and expiratory muscle may be responsible for the restrictive changes of lung function in SLE $^{10,20,21,22}$. Weakness of the respiratory muscle caused by impairment of the nervous system also causes impairment of lung function ${ }^{10,19}$. Although each of these conditions have little effect on respiratory function but their combined effects could contribute to significant restrictive ventilatory defects.

In the present cross-sectional study the exact mechanisms involved for the decrement of lung functions in patients of SLE of different durations cannot be elucidated. Here the decreased percentage of predicted values of $\mathrm{FVC}, \mathrm{FEV}_{1}$ in patients of SLE in comparison to the apparently healthy subjects is most likely due to pulmonary fibrosis and bronchial narrowing as a result of chronic inflammation in lung tissue. Again decreased these lung functions in SLE patients may be due to neurological involvement or respiratory muscle weakness. So, obstructive and restrictive features all together may develop in patients with SLE.

Again, reduced values of $\mathrm{FVC}, \mathrm{FEV}_{1}$ were found with different duration of SLE. These indicated that duration of disease influences the degree of deterioration of lung but were not supported by the significant negative correlation of these parameters with duration of SLE.

This study revealed that pulmonary ventilatory functions may be lower in patients of female SLE and the reduction is inconsistently associated with duration of the disease.

\section{References}

1. Hahn BH. Systemic Lupus Erythematosus. In: Kasper D, Braunwald E, Fauc AS, Hausen SL, Longo DL. editors. Harrison's principles of Internal medicen. NY: MC Graw-Hill; 2005;1960-67.

2. Kumar P, Clark M. Kumar and Clark clinical medicine. $6^{\text {the }}$.London: Elsevier Saunders; 2005;574-576.

3. Roy JS, Das PP, Datta A. SLE in pregnancy. BSMMU J. 2010;3:54-59.

4. Tierney LM, Mcphee ST, Papadakis MA. Current medical diagnosis and treatment. $46^{\text {th }}$ ed. Connecticut: Appleton\& Lange; 2006;833-37. 
5. Silberstein SL, Barland P, Grayzel AL, Koerner SK. Pulmonary dysfunction in systemic lupus erythematosus: prevalence classification and correlation with other organ involvement. J Rheumatol. 1980;7:187-95.

6. Paran D, Fireman E, Levartovsky D, Elkayam O, Kaufman I, Litinsky I, Caspi D, Koifman B, Keren G, Schwrz Y. Pulmonary dysfunction in Systemic lupus erythematosus and anty-phospholipid syndrome patients. Scandinavian Journal of rheumatology. 2007;36:285290 .

7. Kakati S, Doley B, Pal S, Deka UJ. Pulmonary Manifastations in Systemic Lupus Erythematosus with special reference to HRCT. JAPI. 2007;55:839-841.

8. Eisenberg H, Dubois EL, Sherwin RP, Balchum OJ. Diffuse Interstitial Lung Disease in Systemic Lupus Erythematosus. Ann Intern Med. 1973;79:37-45.

9. Chick TW, Dehoratius RJ, Skipper BE, Messner RP. Pulmonary disfunction in Systemic Lupus Erythematosus without pulmonary symptoms. J Rhumatol. 1976;3:262268.

10. Amra B, Mirzael MR, Bonakdar ZS, Golshan M. Respiratory Muscle Funcion and Spirometry in Patients with Systemic Lupus Erythematosus .Tanaffos. 2006;5:53-58.

11. Eichacker PQ, Pinsker A, Epstein A, Schiffenbauer J, Grayzel A. Serial pulmonary function testing in patients with systemic lupus erythematosus. Chest. 1988; 94:12930 .

12. Andonopoulas A, Condantopoulos $\mathrm{SH}$, Calanapoulas V, Drosos AA, Acritidis NC, Moutsopou HM. Pulmonary function of non-smoking patients with systemic lupus erythematosus. Chest. 1988;94:312-15.

13. Rolla G, Brussino MT, Bertero MT, Bucca C, Converso M, Caligaris-cappio F. Respiratory function in Systemic Lupus Erythematosus: relation with activity and severity. Online [Internet] [Cited 2010] Available from http//lup. sagepub.com/5/1/38.short.

14. Weninrib L, Sharma OP, Quismorio FP. A longterm study of interstitial lung disease in Systemic lupus Erythematosus. Semi Arthritis Rheum. 1990;20:48-56.

15. Ong YY, Chew CH, Feng PH. Pulmonary function in systemic lupus erythematosus. Singapore Medical Journal. 1978;19:1.
16. Parvin N, Dus DK, Haque FRM, Nabi M, Haque MM. Cutaneous Manifestation of Systemic Lupus Erythematosus. Journal medicine. 1997;8:44-48.

17. Ali MO, Begum S, Begum N, Ali T, Ferodusi S. PEFR and FEF in type 2 diabetis mellitus and their relationship with it's duration. J Bangladesh Soi Physiol. 2010;5:1419.

18. Akhter P. Assesment of some aspects of spirometric lung function status in hypothyroid female. [M. Phil Thesis] [Dhaka]. Bangabandhu Sheikh Mujib Medical University; 2009;130.

19. Traynor AE, Corbridge TC, Eagan AE, Barr WG, Liu Q, Oyama, Burt RK. Prevalence and Reversibility of pulmonary dysfunction in Reftractory systemic lupus

20. Grennan DM, Howie AD, Moran F, Buchanan WW. Pulmonary involvement in systemic lupus erythematosus. Ann Rheum Dis. 1978;37:536-39.

21. Jongste JCD, Neijens HJ, Duiverman EJ, Bogaard JM, Keffebijn KF. Respiratory tract disease in Systemic Lupus Erythematosus. Archives of disease in children, 1986;61:478-483.

22. Guleria R, Pangtey G. Lung in SLE. Indian Journal of rheumatology. 2007;2:131-132.

23. Kumar V, Abbas AK, Fausto N, Aster JC. Robbins and Cotran Pathologic Basis of disease. $8^{\text {th }}$ ed. India: Elsevier Saunders; 2010;215-220.

24. Gill LM, Quisel AM, Rocca PV, Walters DT . Diagnosis of Systemic Lupus Erythematosus. Am Fam Physician. 2003;68:2179-2187.

25. Colledge NR, Walker BR, Ralston SH. Davidson's Principles and Practice of Medicine. 21 $1^{\text {st }}$ ed. China: Elsevier Limited; 2010.

26. WHO Definition, Diagnosis and Classification of Diabetes Mellitus and its complication. Report of a WHO Consultation. Geneva: WHO; 1999:27

27. American Diabetic Association. Clinical Practical Recommendation. Diabatic Care.2008:31:8.

28. Martin L. The essential for patient care and evaluation. St. Louis: Mosby Yearbook Company; 1987;172-186.

29. Tsang HYH, Lee SL, Wong K, Lau YL. Prevention of respiratory function abnormalities in asymptomatic 
Chinese patients with juvenile onset systemic lupus erythematosus. HKJ Paediatr. 2006;11:199-204.

30. Shirai T, Herose S. Molecular pathogenesis of SLE. Springer Semin Immun. 2006;28:79-82.

31. Kamen DL, Strange C. Pulonary disfunctions of systemic Lupus Erythematosus. Clin Chest Med. 2010;31:479-488.
32. Owens G R, Fino G J, Herbert D L, Steen V D, Medsger T A, Pennock BE, Cottrell J J, Rodnan G P, Roger R M. Pulmonary function in progressive systemic Sclerosis. Comparison of CREST syndrome. Chest. 1983;84:546550 . 